\title{
ONE ROOF JUDICIAL SYSTEM IN INDONESIA
}

\author{
Sufiarina and Efa Laela Fakhriah ${ }^{1}$
}

\begin{abstract}
Judicial power as an independent and autonomous power must be free from any intervention and power, thus ensuring that judges possess independence and impartiality in handling cases. One of the measures for enhancing the independence and autonomy of the judiciary is by placing it under the one roof judicial arrangement developed by the Supreme Court, both from the judicial as well as the non-judicial technical aspects. Up to the present time, endeavors for bringing the four court jurisdictions under the one roof judicial arrangement developed by the Supreme Court have not been completely materialized, due to the existing dualism in judicial power at various courts. The objective of this research is to understand the developments in the endeavors towards bringing the Indonesian judicial system under the one roof judicial arrangement developed by the Supreme Court. The type of research applied is descriptive normative juridical research, namely legal research based on examining secondary data. As the research results indicate, the one roof system developed by the Supreme Court is already being implemented, with the exception of the Military Court and the Tax Court within the State Administration Court jurisdiction.
\end{abstract}

Keywords: one roof judicial arrangement; judicial power.

\section{Introduction}

The 1945 Constitution of the State of the Republic of Indonesia, in the third amendment adopted on November 10, 2001, reasserts that Indonesia is a state based on the rule of law. ${ }^{2}$ The main principles of a state based on the rule of law are the principles of legality, independent judiciary, and the protection of human rights. An independent judiciary must be "free" from influence by the government or any other (extra judicial) influence. The need for an independent judicial power, free from influence by any other power, has been universally recognized and accepted. ${ }^{3}$ In other words, without autonomous justice and an independent judicature, it is virtually impossible to create democracy and a state based on the rule of law.

In state administration practices, the state governance system or ad-

\footnotetext{
${ }^{1}$ Lecturer in Faculty of Law, Universitas Padjajaran and Tama Jagakarsa. Electronic mail contact at sufiarina_01@yahoo.com.

${ }^{2}$ The 1945 Constitution, Third Amendment, Chapter I Concerning Form and Sovereignty, Article 1 paragraph (3).

${ }^{3}$ Bagir Manan and Kuntana Magnar, Beberapa Masalah Hukum Tata Negara Indonesia, (Some Constitutional Law Related Issues in Indonesia), Bandung: Alumni, 1993, p. 160.
} 
ministration requires certain powers, and such powers are limited by law. ${ }^{4}$ Related to power, another doctrine which has contributed to the creation of the idea of state based on the rule of law has been Montesquieu's doctrine on the separation of powers. Montesquieu's doctrine on the separation of powers has been more commonly known as trias politica (three branches of power). Montesquieu states as follows: "Again there is no liberty, if the judiciary power be not separated from legislative and executive. Were it joined with the legislative, the life and liberty of the subject would be exposed to arbitrary control, for the judge would then be the legislator. Were it joined with the executive power, the judge might behave with violence and oppression" ${ }^{5}$

Under Law Number 14 Year 1970 concerning the Basic Provisions on Judicial Power, the provisions on judiciary institutions create dualism since they stand on two different footings. On the one hand, they are based on the Supreme Court (judicative) related to judicial technical aspects, while on the other hand they rest on the related ministry (executive).

While the concept of a contemporary state based on the rule of law absolutely requires the independence and autonomy of judiciary institutions in the form of courts that are independent and free from executive influence as a prerequisite of a state based on the rule of law, in reality, judicial power in Indonesia is still being positioned under the control of executive power. ${ }^{6}$ Steps to remedy such condition were taken in Law No. 35, Year 1995 concerning the Amendment to Law No. 14 Year 1970, notably focusing on two matters; first, transferring judiciary bodies as intended in Article 10 paragraph (1) of Law No. 14 Year 1970, from the organizational, administrative and financial aspects to the Supreme Court's authority, and second, the settlement of disputes related to the interconnection of jurisdictions. Law No. 35 Year 1999 also calls for the gradual transfer of the above mentioned organizational, administrative and financial aspects within a time frame of no longer than 5 (five) years. ${ }^{7}$

Law No. 14 Year 1970 amended with Law No. 35 Year 1999 was subsequently replaced by Law No. 4 Year 2004 concerning Judicial Power, which was further amended by Law No. 48 Year 2009. The new spirit brought by the law on Judicial Power after Law No. 14 Year 1970 was the overall (one-roof) arrangement of the existing judiciary bodies under the Supreme Court so as to be furthermore developed by the Supreme Court.

Law No. 4 Year 2004 concerning Judicial Power replacing Law No. 14 Year 1970.In Article 13 of Law No. 4 Year 2004 it is stated that:

"The organization, administration and financial matters of the Supreme Court and judiciary bodies under the Supreme Court shall be under the authority of the Supreme Court".

"The organization, administration, and financial matters of the Consti-

${ }^{4}$ Bahder Johan Nasution, Negara Hukum dan Hak Asasi Manusia, (State Based on the Rule of Law and Human Rights). Bandung: MandarMaju, 2011, p. 74, compare to Yusril Ihza Mahendra, Dinamika Tata Negara Indonesia, Kompilasi Aktual Masalah Konstitusi Dewan Perwakilan dan Sistem Kepartaian, (The Dynamics of Indonesian Constitutional Law, A Compilation of Current Constitutional Issues Related to the House of Representatives and the Party System). Jakarta: Gema Insani Press, 1996, p.41

${ }^{5}$ Hotma P Sibuea, Asas Negara Hukum, Peraturan Kebijakan, Asas-asas Umum Pemerintahan yang Baik, (The Principles of State Based on the Rule of Law, Policy Regulations, General Principles of Good Governance). Jakarta: Penerbit Erlangga, 2010, p. 25.

${ }^{6}$ Hasbi Hasan, Kompetensi Peradilan Agama, (The Competence of the Religious Court in the Settlement of Sharia Economy Disputes). Jakarta: Gramata Publishing, 2010, p. 54.

${ }^{7}$ See Article 11 A of Law No. 35 Year 1999. 
tutional Court shall be under the authority and competence of the Constitutional Court". [unofficial translation]

The above provisions continued to be maintained under Law No.48 Year 2009 concerning Judicial Power as ius constitutum.

In Indonesia, judicial power is exercised by a Supreme Court and the judiciary bodies under it within the court of general jurisdiction, religious court, military court, state administration court, and a Constitutional Court. ${ }^{8}$

Accordingly, the implementers of judicial power in Indonesia rest on the pillars of the Supreme Court and the Constitutional Court. The respective functions and authorities of each of them are provided for under a law. The organization, administration and financial matters of the Supreme Court and the judiciary bodies under it are under the authority of the Supreme Court. ${ }^{9}$ The organization, administration and financial matters of the Constitutional Court fall under the authority and competence of the Constitutional Court. ${ }^{10}$

By bringing the judiciary under the one roof system under the authority of the Supreme Court, it is certainly expected to create an increasingly stronger and more solid independence and impartiality of judicial power.

The foregoing is intended to mean eliminating intervention by the executive in the organization, administration and financial matters of judiciary bodies, and at the same time judges as adjudicators being increasingly independent from intervention by the executive, ensuring that the autonomy of the judiciary is materialized.

After the amendment to the Judicial Power law with Law No. 35 Year 1999, and more than a decade later, have these measures for introducing the one-roof judiciary system been completely enforceable?

\section{Theoretical Study}

Independent judiciary institutions are the pillars of a state based on the rule of law, and the purpose of independent judicial power is to ensure that there is no extrajudicial intervention, particularly by the executive and legislative branches of power, in the implementation of the judiciary function. ${ }^{11}$ With an independent power of judiciary institutions, it is expected that judiciary institutions will become a strong mechanism for maintaining the constitution and justice. ${ }^{12}$ However, there is a need for legal mechanism in the form of legislation concerning the implementation of judicial functions, in order to be able to prevent an unlimited exercise of the powers of judiciary institutions.

As implementers of judicial power namely as state judicature ${ }^{13}$ their

${ }^{8}$ See Article 18 of Law No. 48 Year 2009, in accordance with the provisions of Article 24C paragraph (1) of the 1945 Constitution of the State of the Republic of Indonesia, the Constitutional Court has the competence to hear cases at the first and final instance.

${ }^{9}$ See Article 21 of Law No. 48 Year 2009.

${ }^{10}$ See Article 29 paragraph (4) of Law No. 48 Year 2009.

${ }^{11}$ Ahmad Mujahidin, Peradilan Satu Atap di Indonesia, (One-Roof Judicial System in Indonesia), Bandung: Refika Aditama, 2007, p. 52.

12 Ibid, p. 53.

${ }^{13}$ All courts in the entire territory of the state of the Republic of Indonesia are state courts provided for under the law. This is articulated in Article 2 paragraph (3) of Law No. 48 Year 2009 and in Article 2 paragraph (2) stating that "The state judicature is applying and enforcing the law and justice based on 
existence and role are provided for under law. As state judicature, they have the task and function to implement and enforce law and justice based on Pancasila, and the 1945 Constitution of the State of the Republic of Indonesia.

Introducing the one roof system is part of the efforts to unite the development of judiciary institutions under the Supreme Court. Such development involves both judicial technical and judicial non-technical aspects by the same single entity.

The above described development is different from the previous way of dealing with this mater, when the development of judiciary bodies used to be conducted in a dualistic manner, namely with the Supreme Court handling judicial technical aspects, while judicial non-technical matters were dealt with by the relevant Ministries such as the Ministry of Law and Human Rights for courts of general jurisdiction, and the State Administration Court and the Ministry of Religious Affairs for religious courts. Ministers are political officials responsible to assist in achieving the executive's agenda, and in fulfilling such function, they are in fact often contradictory to Justice in many ways. Full control of the management of judicial personnel by a governmental department is bound to increase the likelihood of political intervention. ${ }^{14}$ Dualism in the development of the judiciary is certain to pose a threat on the independence of judges as implementers of judicial power.

With the development of judiciary being removed from the relevant ministries, the Supreme Court has the formal juridical authority as the central implementer of judiciary institutional power to manage, develop and supervise four judiciary institutions under its competence, namely: general and appeals courts, religious courts of the first instance and appeals level, first state administration courts of the first instance and at the appeals level, as well as military courts of the first instance, military high courts and primary military courts in judicial technical matters as well as the development of administration, organization and finance related aspects, and other basic functions. ${ }^{15}$ The one-roof system is a matter of independence of judicial power (judicative power). ${ }^{16}$

Judicial non-technical aspect means the development of organizational, administration and financial aspects. Organization is the status, functions, authorities and the structure of the organization concerned. ${ }^{17}$ Administration includes personnel, state assets, finances, archives and documents, ${ }^{18}$ whereas financial matters refer to the current budget. ${ }^{19}$

As for the technical judicial aspects, viewed from the normative point of view, there are indeed no specific and explicit provisions in a law or regulation concerning the definition of technical judicial aspects; however, based on the systematic interpretation method (interpretation by examining the provisions of other laws), several provisions of Law No. 48 Year 2009 concerning

Pancasila."

${ }^{14}$ Sebastian Pompe, Runtuhnya Institusi Mahkamah Agung, (The Collapse of the Institution of the Supreme Court). Jakarta: Lembaga Kajian dan Advokasi untuk Independensi Peradilan, 2012, p. 176.

${ }^{15}$ Ahmad Mujahidin, op-cit, p. 23.

16 Ibid.

${ }^{17}$ Presidential Decree No. 21 Year 2004 concerning the Transfer of the Organization, Administration and Finances of the court of general jurisdiction, the state administration court and the religious court to the Supreme Court.

${ }^{18}$ Ibid.

${ }^{19}$ Ibid. 
Judicial Power, among other things Article 4 Paragraph (1), Article 40 Paragraph (1), Article 40 Paragraph (2), and Article 42, provide an understanding that judicial technical aspects are matters related to giving independence/autonomy to judges enabling them to make decisions concerning the substance of cases based on instruments of evidence presented in the court hearing and based on firm belief as provided for under the law. ${ }^{20}$

\section{III.Research Methodology}

This research applies the normative juridical research methodology, ${ }^{21}$ by conducting research of secondary data in the form of primary legal materials namely laws and regulations such as the law concerning judicial power, the law concerning the Supreme Court and other judiciary institutions. The aforementioned primary legal materials are supported by secondary legal materials in the form of articles written by experts and results of research related to the issue being discussed, as well as tertiary data. This normative research examines the level of vertical and horizontal synchronization of laws and regulations related to judicial power as umbrella regulations and or among the regulations of various judiciary institutions. It is followed by a descriptive analysis aimed at obtaining answers to the issues being under discussion.

\section{A. Discussion}

Independency and One-Roof Arrangement of Judicial Power

Under the 1945 Constitution of the State of the Republic of Indonesia, judicial power is independent power implemented by a Supreme Court and the judiciary bodies under it within the court of general jurisdiction, the religious court, the military court, the state administration court, and by a Constitutional Court, with the aim of organizing the judiciary for enforcing law and upholding justice.

The independency of judiciary institutions is inseparable from various underpinning factors, which include both internal factors such as institutional structure, judges and legal provisions, as well as external factors such as power, politics and public legal awareness. ${ }^{22}$

Steps have been taken towards the structural strengthening of judicial power by introducing a vision for reform through amendment to the state constitution, namely the 1945 Constitution. ${ }^{23}$ While provisions on judicial power under the 1945 Constitution consisted of only 2 (two) articles and 3 (three) paragraphs, ${ }^{24}$ following the amendment they were expanded into 5

\footnotetext{
${ }^{20}$ Arieflawyer.blogspot.com/Gerai Hukum, Masalah Teknis Yudisial, (Technical Judicial Issues), retrieved on January 2, 2013.

${ }^{21}$ See Soerjono Soekanto and Sri Mamudji, Penelitian Hukum Normatif, (Normative Legal Research), Jakarta: Raja Grafindo Persada, 2009, p. 14. See also Ronny Hanitijo Soemitro, Metodologi Penelitian Hukum dan Jurimetri, (Legal Research Methodology and Jurimetri), Ghalia Indonesia, 1990, p. 11.

${ }^{22}$ Ahmad Mujahidin, op-cit, p. 15.

${ }^{23}$ Such legislative product concerning judicial power under the 1945 Constitution has been stipulated in the third amendment in the $7^{\text {th }}$ Plenary Meeting (continuation 2) in the Annual Session of the People's Consultative Assembly (MPR) on November 9, 2001.

${ }^{24}$ Provisions on judicial power under the 1945 Constitution prior to the amendment were set forth Article 24 and Article 25. The provisions of Article 24 state only that: (1) Judicial power shall be imple-
} 
(five) articles consisting of a total of 19 (nineteen) paragraphs. ${ }^{25}$

In his theory of trias politica about the separation of powers, Montesquieu puts forward the independence of each of the state organs (legislature, executive and judicature). Montesquieu's theory is based on the fundamental idea that any intervention or any single concentration of power in the legislature, executive and judicature (all or two among the three) is bound to create arbitrary rule or governance, hence the (organs) of state governance must be separated, or in other words they must be independent from each other. ${ }^{26}$

The 1945 Constitution uses the term "judicial power" as an equivalent of judicative power, rechtspraak or judiciary ${ }^{27}$ Judicial power is independent and free from intervention by any other power. Such judicial power is characteristic of a democratic state based on the rule of law. Accordingly, judicial power and a state based on the rule of law form an inseparable unity, which means that judicial power is the main aspect of a state based on the rule of law. In the absence of such aspect, no state can be considered as a state based on the rule of law. ${ }^{28}$ The theory of the separation of powers or the distribution of powers among state organs is one of the general characteristics of a state based on the rule of law.

The doctrine of triaspolitica also supports the doctrine of "state based on the rule of law". These two doctrines are interrelated and inseparable, just like the two sides of the same coin. In the separation or distribution of powers, an emphasis is also constantly placed on independent judicial power. ${ }^{29}$ The 1945 Constitution does not adopt the doctrine of separation of powers as put forward by Montesquieu; rather, it adopts the system of distribution of powers. In principle, the doctrine of separation of powers (Montesquieu) teaches the independence of each state organ (legislature, executive and judicature). Montesquieu puts forward that any combination (in one hand) of the legislature, executive and judicature (all or two among the three) is certain to create arbitrary rule or governance.

In order to prevent arbitrariness, state organs must be separate from each other, each of them should be independent vis-à-vis the other ${ }^{30}$ Even though not based on triaspolitica, the separation and authorities of each branch of power are expressly set forth and cannot be eliminated by law or

mented by a Supreme Court and other judicial bodies in accordance with the law; (2) The organizational structure and authorities of such judicial bodies shall be provided for under a law. Whereas Article 25 only provides that: "The requirements for the appointment and dismissal of judges shall be set forth in a law." [unofficial translation]

${ }^{25}$ For the complete text refer to the provisions of Articles 24, 24A, 24B, 24C and Article 25 of the 1945 Constitution following amendment.

${ }^{26}$ Charles Louis De Secondad Montesquieu, The Spirit of the Laws, (Transl.) M. Khoiril Anam, Dasar - Dasar Ilmu Hukum and Ilmu Politik, (The Fundamentals of the Science of Law and Political Science), Bandung: Nusa Media, 2007, p. 150.

${ }^{27}$ Bagir Manan, Sistem Peradilan Berwibawa,(A Judicial System with Recognized and Observed Authority, (A Quest), ibid, p. 120.

${ }^{28}$ Abdullah Zaini, Pengantar Hukum Tata Negara, (An Introduction to Constitutional Law), Jakarta: Pustaka Sinar Harapan, 1991, p. 78. Compare to Padmo Wohjono, Indonesia Negara Berdasarkan atas Hukum, (Indonesia, A State Based on the Rule of Law), Jakarta: Ghalia Indonesia, 1982, p. 12.

${ }^{29}$ C.W. Van Der Pot,-A.M. Donner, Handboek van het Nederlandse Staats recht, Tjeek Willink, zwole, 1989, p. 15-17.

30 Montesquieu, The Spirit of the Laws, as quoted by Bagir Manan in Sistem Peradilan Berwibawa (Suatu Pencarian, (A Judicial System With Recognized and Observed Authority, (A Quest).) Yogyakarta: UII Press, 2005, p. 121. 
legislative products of lower hierarchy. ${ }^{31}$

In such context, in its state constitution, namely the 1945 Constitution, Indonesia does not adopt the concept of separation of powers ${ }^{32}$ which separates executive, legislative and judicative powers. It is quite obvious, not only from the fact that the formal text of the 1945 Constitution does not contain express provisions concerning the separation of powers, ${ }^{33}$ but also as reflected in Soepomo's statement in the BPUPKI session, namely that "the principle adopted in the Constitution which is in the process of being formulated is not based on Montesquieu's version of the Trias Politica doctrine (separation of powers $),{ }^{34}$ rather, it adopts the system of distribution of power only in its fundamental functions which are separated and submitted to distinct hands. ${ }^{35}$

In the context of materializing independent judicial power as well as a clean judiciary possessing a recognized and observed authority, the structuring of the judiciary system has been conducted with its integral development by the Supreme Court, which means that all matters related to the judiciary, both in view of the judicial technical aspects as well as the judicial non-technical matters (organizational, administrative and financial matters) are under the Supreme Court's authority, whereby the courts of each jurisdiction are provided for under law. ${ }^{36}$ Accordingly, the independence of judicative power is purely a result of separating it from the executive, which has been considered as undermining judicial power all this time.

\section{B. Four Court Jurisdictions under the Supreme Court}

Judicial power is implemented by the Supreme Courtby organizing 4 (four) court jurisdictions under it, all of which have the status of state courts, including the court of general jurisdiction, the religious court, the military court, and the state administration court.

One thing in common is that in each of these court jurisdictions there is institutional hierarchy. Legislators have set the principle which serves as a pillar in each of these court jurisdictions, namely the principle of institutional hierarchy of judiciary bodies, particularly as set forth in the Court of General Jurisdiction, the Religious Court, the State Administration Court and the Mili-

${ }^{31}$ Padmo Wahjono, Indonesia Negara Berdasarkan atas Hukum, (Indonesia, a State Based on the Rule of Law), Jakarta: Ghalia Indonesia, 1982, p. 12.

32 The theory of the Separation of Powers was put forward by Montesquieu (1689-1721AD) in his work The Spirit of the Laws. Montesquieu's book has been translated into the Indonesian language (Bahasa Indonesia) by M. Khoiril Anam, under the title Dasar - Dasar Ilmu Hukum and Ilmu Politik,(The Fundamentals of the Science of Law and Political Science), Bandung: Nusa Media, 2007.

${ }^{33}$ Related to judicial power under the 1945 Constitution, it was only stated that: "judicial power shall be implemented by a Supreme Court and other judicial bodies according to the law. The organizational structure of such judicial bodies shall be provided for under a law". Refer to the provisions of Article 24 of the 1945 Constitution. Following the amendment, the provisions regarding such matter became more specific, stating that: "Judicial power shall be an independent power for organizing the judiciary with the aim of enforcing law and upholding justice. Refer again to the provisions of Article 24 paragraph (1) of the 1945 Constitution.

${ }^{34}$ Miriam Budiarjo, Dasar - Dasar Ilmu Politik, (The Fundamentals of Political Science), Jakarta: PT. Gramedia Pustaka Utama, 2000, ed. XI p. 155.

${ }^{35}$ It is referred to as division of power based on the view that sovereignty is in the hands of the people as the manifestation of the entire sovereign people. See Jimly Asshiddiqie, Pokok-Pokok Hukum Tata Negara Indonesia Pasca Reformasi, (The Principles of Indonesian Constitutional Law in the Post-Reform Era), Jakarta: Buana Ilmu Populer kelompok Gramedia, 2007, p. 166.

${ }^{36}$ Observe Article 21 paragraph (1) and paragraph (2) of Law No. 48 Year 2009. 
tary Court. From the institutional point of view there are two levels, with the Court of General Jurisdiction, the Religious Court, the State Administration Court, and the Military Court constituting the lower courts, or the courts of first instance. The High Court, the High Religious Court and High State Administration Court, as and the Military High Court are the appellate courts. At the top of the court system consisting the above mentioned court jurisdictions is the Supreme Court as the cassation court or the ultimate level of the judiciary for all court jurisdictions.

Based on Law No. 14 Year 1970, the judicial non-technical aspect of the court of general jurisdiction is organized by the Department of Law and Human Rights, while the judicial technical aspect isorganized by the Supreme Court. Adjustment was made to such dualistic organization of the court of general jurisdiction under the provisions of Law No. 48 Year 2009 concerningJudicial Poweras well as Law No. 3 Year2009 concerningThe Supreme Court. Such adjustment was implemented through Law No. 49 Year 2009 concerningThe Second Amendment to Law No. 2 Year 1986 concerningThe Court of General Jurisdiction, setting forth the basic principle policy that in all matters related to the court of general jurisdiction, supervision at the highest level concerning judicial technical as well as non-judicial matters, namely organization, administration and financial matters, is under the Supreme Court's authority. Prior to that, based on Law No. 2Year 1986 it was stated that the technical organization of the court of general jurisdiction is conducted by the Supreme Court, while the organizational, administrative and financial aspects are organized by the Minister of Justice.

As for the religious court, limited amendment was also made to Law No. 7 Year 1989 throughLaw No. 3 Year 2006. Such limited amendment was an integral part of the endeavors aimed at reinforcing consistency in the principle of independent judicial power.

As for the religious court, adjustment was made through Law No. 3 Year 2006 concerning the Amendment to Law No. 7 Year 1989 concerning the Religious Court, in Article 5 stating as follows: "The judicial technical organization, organizational, administrative and financial matters of the court are conducted by the Supreme Court". [unofficial translation]Accordingly, the organization of aspects related to the organization, administration and financial matters of the religious court, previously under the authority of the Department of Religious Affairs, was transferred to the Supreme Court.

An important aspect of the adoption of Law No. 3 Year 2006 is rather evident from the General Elucidation, notably in the part which reads as follows: ${ }^{37}$ The 1945 Constitution of the State of the Republic of Indonesia, in Article 24 paragraph (2) sets forth that the Religious Court is one of the judiciary bodies implementing judicial power under the Supreme Court together with other judiciary bodies within the Court of General Jurisdiction, the State Administration Court and the Military Court. The Religious Court is one of the judiciary bodies implementing judicial power for the purpose of organizing law enforcement and providing justice to justice seekers in certain disputes among adherents of the religion of Islam in the areas of marriage, inheritance (waris), testament (wasiat), bequest (hibah), endowments (waqaf), alms (zakat), charity (infaq), voluntary charity (shadaqah) and sharia economy. Such affirmation of the competence of the religious court is aimed at creating the

${ }^{37}$ See General Elucidation on Law No. 3 Year 2006. 
legal basis for the religious court in handling the above specified cases, including violations of the Marriage Law and the implementing regulations thereof, as well as reinforcing the legal basis for the Sharia Court (Mahkamah Syariah) in implementing its competence in the field of jinayah (criminal law) based on qanun (equivalent to regional regulation).

The enactment of Law No. 3 Year 2006 is aimed at the synchronization of all aspects and responsibilities related to organization, administration and financial matters of judiciary bodies within the religious court vis-à-vis the provisions of Law No. 4 Year 2004. Accordingly, while all aspects and responsibilities related to organization, administration and financial matters of judiciary bodies within the religious court used to be under the authority of the Department of Religious Affairs, following the adoption of Law No. 3 Year 2006 all of the foregoing were submitted and transferred so as to become the authority of the Supreme Court. ${ }^{38}$ The regulation on such transfer of authority to the Supreme Court ${ }^{39}$ has been essentially realized based on Law No. 4 Year 2004.

Similar has also been the case with the State Administration Court, whereby it is basically set forth in Article 7 of Law No.5 Year 1986 concerning organization that: "The technical organization of the state administration court shall be conducted by the Supreme Court, whereas organizational, administrative and financial organization shall be conducted by the Department of Justice". [unofficial translation] Law No. 9 Year 2004 concerning the Amendmentto Law No. 5 Year 1986 and Law No. 51 Year 2009concerningthe Second Amendment to Law No. 5 Year 2009 set forth as follows: "Judicial technical development, organization, administration and financial related matters shall be conducted by the Supreme Court." [unofficial translation]

In general, the amendment to Law No. 5 Year 1986 concerning the State Administration Court as amended with Law No. 9 Year 2004 concerning the Amendment to Law No.5 Year 1986 concerning the State Administration Court is basically aimed at materializing the organization of independent Judicial Power and a clean judicature possessing authority which is recognized and observed, implemented through an integral arrangement of the judiciary system, specifically the state administration court which, according to the Constitution, is one of the courts under the Supreme Court which has the competence to examine, hear and adjudicate state administration related cases. ${ }^{40}$

\section{Dualism in organization still exists}

The law on Judicial Power, in this case Law No. 48 Year 2009, is the organic law, and at the same time the basis and general framework which lays down the principles, fundamentals and guidelines for courts of all jurisdictions in Indonesia.

This law is the umbrella law for all laws and regulations, judiciary bodies, management, administration and court proceedings. Any juridical amendment to judicial power must reach the various laws and regulations for which

\footnotetext{
${ }^{38}$ Syamsuhadilrsyad, EksistensiPeradilan Agama PascaLahirnya Law No. 3 Year 2006, (The Existence of the Religious Court Following the Adoption of Law No. 3 Year 2006).Paper, July 10, 2006, p. 10.

39 HasbiHasan, KompetensiPeradilan Agama DalamPenyelesaianSengketaEkonomiSyariah, (The Competence of the Religious Court in the Settlement of Sharia Economy Disputes). Jakarta: Gramata Publishing, 2010, p. 71.

${ }^{40}$ General Elucidation on Law No. 51 Year 2009.
} 
it serves as an umbrella law, including the various policy related regulations (beleidsregels) as well as judiciary practices as articulated in case law or decisions made by judges.

Even though from the organizational structural point of view, it is set forth in Article 21 Law No.48 Year 2009 that: "The organization, administration and financial matters of the Supreme Court and the judiciary bodies under it are under the authority of the Supreme Court" [unofficial translation], from the legal formal point of view it cannot be considered that the judiciary system constitutes completely a one roof system. It is due to the fact that, even though some courts are juridical-technically under the Supreme Court's arrangement, their non-judicial technical organization has not yet been transferred to the Supreme Court, namely the Military Court and the Tax Court.

The Military Court

In connection with the Military Court, which is provided for under Law No. 31 Year 1997, it is stated in Article 6 that, "Judicial technical organization within the military court is conducted by the Supreme Court". At the same time, Article 7 also sets forth that, "The organization and procedure, the financial administrative matters of the organs of the court and the Office of the Military Prosecutor shall be conducted by the Commander". [unofficial translation]

The one roof system arrangement of the judiciary with the judicial-technical as well as the judicial non-technical organization thereof being placed under the Supreme Court is a conditio sine qua non for its independence and being free from the influence of the executive, in order to demonstrate that Indonesia is a state based on the rule of law referred to as rechtstaat.

It is evident from the regulations of the respective court jurisdictions that some court jurisdictions are not completely under the arrangement of the Supreme Court, namely the courts of the Military Court jurisdiction. Only the judicial-technical aspects of military courts are arranged by the Supreme Court, whereas in view of the organizational, administration and financial aspects, they are under the arrangement of the Commander. ${ }^{41}$

The military court is the implementer of judicial power within the Armed Forces for the purpose of enforcing law and upholding justice with due observance of the interest for organizing state security and defense.

The military court is a body implementing judicial power within the military jurisdiction which includes the Military Court, the Military High Court, the Primary Military Court and the combat Military Tribunal, ${ }^{42}$ with the Supreme Court at the top as the Highest State Court. ${ }^{43}$

Courts of the military jurisdiction ${ }^{44}$ consist of the following:

Military Courts of the first instance for criminal cases involving a defendant with the rank of captain or lower;

The Primary Military Court, which is an appeals court for criminal cases decided by the Military Court at the first instance. The Military High Court is also a Court of the first instance for the following:

\footnotetext{
${ }^{41}$ Article 10 of the 1945 Constitution of Indonesia: "The President holds the supreme power over the Army, the Navy and the Air Force". [unofficial translation] It means that the Commander-in-Chief of the Armed Forces (TNI) is under the President's authority.

${ }^{42}$ See Article 1 paragraph (1) of Law No. 31 Year 1997.

${ }^{43}$ See Article 8 Paragraph (2) of Law No. 31 Year 1997.

${ }^{44}$ See General Elucidation on Law No. 31 Year 1997.
} 
a) Criminal cases in which one of the defendants has the rank of a Mayor or a higher rank; and

b) Disputes involving Armed Forces related administrative claims.

The Primary Military Court, which is the appeals court for criminal cases and Armed Forces related state administration disputes decided by the Military High Court;

The Combat Military Tribunal, which is the court of first and final instance for hearing criminal cases committed by Soldiers in combat areas, is a differentiation/specialization of the courts of military jurisdiction. That Court is merely a framework organization which only becomes functional when required and it is only then that the relevant officials are appointed accordingly.

Courts of the military jurisdiction appear to have a different structure as compared to courts of other jurisdictions, namely courts of first instance, appeals courts, with the Supreme Court at the top. In the courts of the military jurisdiction there seem to be 3 levels of judicature before reaching the Supreme Court at the top, while in the other two jurisdictions there are 2 (two) levels of judicature before the Supreme Court at the top.

However, in reality, there are in fact only two levels of judicature among the military courts as well. Differences at the structural level occur only from the point of view of rank personality and the substance of cases. In criminal cases, for instance, there are two structures involved, namely as follows:

In the event of personalities with the rank of Captain or a lower rank, their criminal cases are processed at the first instance at the Military Court and at the appeals level at the Military High Court, with cassation at the Supreme Court.

In the event of personalities with the rank of mayor or a higher rank, their criminal cases are processed at the first instance at the Military High Court, with an appeal that can be filed at the Primary Military Court, and cassation at the Supreme Court.

In Armed Forces related administrative cases, regardless of the rank hierarchy personality, the Military High Court has the authority to conduct the first hearing, appeals against its decisions may be filed with the Primary Military Court, and cassation can be filed with the Supreme Court. There are in fact only two levels of the military courts before reaching the Supreme Court at the top.

At the same time, the Combat Military Court is a special court within the military jurisdiction, the decisions of which are of the first and final instance in hearing criminal cases committed by soldiers in combat areas. The Combat Military Tribunal has an ad hoc function as it is formed only when required.

The juridical technical organization of the judicature within the courts of military jurisdiction is conducted by the Supreme Court, ${ }^{45}$ however, from the organizational, administrative, and financial aspects they are organized by the Commander of the Armed Forces (TNI). ${ }^{46}$

Measures for bringing the courts of military jurisdiction under the oneroof system with full organization by the Supreme Court are yet to be implemented, bearing in mind the characteristics of the military world. The life and organizational structure of the military are marked by a very strong principle

\footnotetext{
${ }^{45}$ Observe Article 6 of Law No. 31 Year 1997.

${ }^{46}$ Observe Article 7 of Law No. 31 Year 1997.
} 
of command unity, with the commander having central position and full responsibility for unity and for his personnel.

Under the constitution of the State of the Republic of Indonesia the President is concurrently the Commander-in-Chief of the Armed Forces (TNI), as stated in Article 10 of the 1945 Constitution, namely that the President holds supreme power over the Army, the Navy and the Air Force. Accordingly, the supreme commander of the Armed Forces (TNI) is under the authority of the President as the executive branch. The President's authority over the Army, the Navy and the Air Force is a consequence of the President's office as the Head of State. Consequently, the court of military jurisdiction is not entirely independent from influence by the executive.

It is therefore rather difficult to place the organization of the courts of military jurisdiction under the umbrella of the Supreme Court. Notwithstanding the above, however, under concept of integrated justice system only the organizational aspect should be handed over to the Commander of the Armed Forces (TNI), while administrative and financial organization should be transferred to the Supreme Court in the context of materializing an independent and impartial judicial power for achieving justice, certainty, and benefit.

\section{Tax Court}

The tax court has special jurisdiction, initially provided for under Law No. 17 Year 1997 referring to it as Badan Penyelesaian Sengketa Pajak (BPSP) (Tax Dispute Settlement Body). By virtue of Law No. 14Year 2002 concerning the Tax Court, BPSP was changed to Tax Court. Accordingly, the Tax Court is the continuation of the BPSP. In the considerations of points $d$ and e of Law No. 14 Year2002, it is stated that the reason for changing BPSP to Tax Court is as follows, among other things:

In view of its existence and position, the BPSP is not yet a judiciary body with the ultimate level at the Supreme Court,

It is therefore necessary to set up the Tax Court which corresponds to the Judicial Power applicable in Indonesia.

Based on the elucidation on the above considerations, the tax court is part of the jurisdiction of judicial power just like the court of general jurisdiction, the religious court, the military court and the state administration court. However, considering that in the Amendment to Article 24 of the 1945 Constitution as well as in Article 10 paragraph (2) of Law No. 4 Year 2004, and Article 18 of Law No. 48 Year 2009 the tax court has not been included as a court within the scope of judicial power, it is theoretically being considered as a special court. ${ }^{47}$

In reality, the existence of the Tax Court, which was officially introduced under Law No. 14 Year 2002, is still inviting controversy, particularly related to the position of the Tax Court within the national judiciary system. There is not a single article in the main body of Law No. 14 Year 2002 indicating specifically the area of the tax court's jurisdiction. There is only a general explanation stating that: "The Tax Court is a special court for hearing tax disputes." [unofficial translation] Similarly, in Law No. 48 Year 2009 concerning Judicial Power there is not a single article referring to the tax court. The tax court is

47 M. Yahya Harahap, Hukum Acara Perdata, (Civil Procedural Law), Jakarta: Sinar Grafika, 2008, p. 188. 
only mentioned in the Elucidation on Article 27 paragraph (1), stating that: "referred to as special courts are, among other things, the juvenile court, the commercial court, the human rights court, the industrial relations court and the fisheries court under the court of general jurisdiction, as well as the tax court which is under the state administration court jurisdiction".

Similar is the case with the state administration court upon searching either Law No. 5 Year 1986 concerning the State Administration Court, Law No. 9 Year 2004 concerning the Amendment to Law No. 5 Year 1986 and Law No. 51 Year 2009 concerning The Second Amendment to Law No. 5 Year 1986. However, in the Elucidation on Article 9A paragraph (1) of Law No. 51 Year 2009 it is stated that: "Special Court is a differentiation or specialization within the jurisdiction of the state administration court, as for example the tax court". [unofficial translation]

Due to the arrangement of judicial power by the Supreme Court in 4 (four) areas of court jurisdiction, based on the above mentioned elucidation on Article 9A paragraph (1) of Law No. 51 Year 2009 it can be stated that the tax court is a special court within the state administration court's jurisdiction, even though in effect there has not been any other special court within the state administration court's jurisdiction to date. Based on the foregoing, the Tax Court is a special court and it belongs to the Jurisdiction of the State Administration Court.

The Tax Court is a judiciary body implementing judicial powerfor taxpayers or tax guarantors seeking justice in tax disputes. ${ }^{48}$ The tax court serves as the implementer of a certain portion of judicial power in the field of taxes between taxpayers or tax guarantors and the relevant officials related to decisions in respect of which claims or appeals may be filed with the tax court.

Even though the intention of the tax court law is to position the tax court within the judicial power system with the Supreme Court at the top, such intention appears to be lacking genuineness in its implementation. By virtue of Article 5, the existence and position of the Tax Court under the Supreme Court is not entirely comprehensive, rather, it is limited to judicial technical organization and management, while organizational, administrative and financial arrangements are handled by the Department of Finance.

The Department of Finance (currently called the Ministry of Finance) is led by a minister, who is also the president's assistant, which means that he is still within the scope of the executive. Accordingly, the tax court as part of judicial power is indeed under the Supreme Court; on the other hand, however, it also partially rests on the executive branch as a result of its being organized by the Ministry of Finance.

The dualism of judicial power under Law No. 14 Year 1970 is concerning the organization of judiciary bodies which, from the judicial technical aspect are under the Supreme Court, and from the non-judicial technical aspect under the relevant Department concerned. Such dualism was brought to an end by eliminating it through Article 13 paragraph (1) of Law No. 4 Year 2004 and Article 21 of Law No. 48 Year 2009, stating that the organization and supervision of all judiciary bodies under the Supreme Court either judicialtechnically or judicial non-technically shall be entirely and comprehensively under the Supreme Court.

The provisions of Law No. 14 Year 2002 concerning the Tax Court which

\footnotetext{
${ }^{48}$ See Article 2 of Law No. 14 Year 2002 concerning the Tax Court.
} 
continue to adopt dualism by determining organization through the Supreme Court in view of judicial technical matters, and through the Ministry of Finance in view of judicial non-technical matters, may be considered as a step backward. With the continued attribution of the executive symbol through the Ministry of Finance with intervention in its administrative, organizational and financial aspects, the independence and autonomy of the tax court become questionable.

Having jurisdiction for the settlement of disputes between taxpayers and the tax office (the state as the collector of taxes), the tax court's jurisdiction is certainly implemented by the executive; while in fact, as part of the judicial power system, it should be released from organization by the ministry of finance. The overall organization of the tax court, both from the judicial technical aspect, as well as from the judicial non-technical aspect related to administration, organization and financial matters should also be handed over to the Supreme Court. By doing so, an integrated justice system would be created.

In the context of the one-roof system, the Tax Court is outside the integration of judicial power under the Supreme Court. Viewed from the aspect of its organization, the judicial technical matters related to the Tax Court are organized by the Supreme Court; however, the organizational, administrative and financial aspects of the Tax Court are organized by the Department of Finance. While in the case of the court of general jurisdiction, the religious court, and the state administration court, they have been integrated in terms of judicial technical as well as judicial non-technical matters (organization, administration and financial) under the organization of the Supreme Court.

With the dualism of judicial power at the Tax Court, whereby non-judicial technical (organization, administration and financial) continue to be organized by the Ministry of Finance, it can be considered that the independence of tax court judges is disrupted as the Ministry of Finance is part of executive power assisting the President in implementing executive power. It can also be concluded that the integration of judicial power has not been fully implemented, as some of judicial power is still being organized by the Ministry of Finance. Consequently, the integration of judicial power is neither complete nor comprehensive at the present time, due to the fact that certain parts of judicial power are still being organized by the executive branch, in this case the tax court, the non-judicial aspects of which are organized by the Ministry of Finance as part of the executive.

On the other hand, the court of general jurisdiction, the religious court and the state administration court are already within the integrated justice system, which is organized by the Supreme Court both from the judicial technical as well as from the judicial non-technical aspects, hence it no longer contains dualism of judicial power.

\section{Conclusion}

Law No. 48 Year 2009 concerning Judicial Power is the umbrella law for judicative power. Out of the four areas of court jurisdiction, the Military Court and the Tax Court are not yet fully under the one roof system of the Supreme 
Court. While from the judicial technical point of view the Military Court is indeed under the organization of the Supreme Court, from the non-technical judicial aspect it still remains under the organization of the Commander of the Armed Forces (TNI).

The organization of the Tax Court related to organizational, administrative as well as financial matters is under the Minister of Finance (the government) while from the judicial technical aspect it is organized by the Supreme Court. At the same time, it needs to be borne in mind that the tax court deals with the settlement of disputes between taxpayers and the government (the state) as the collector of taxes. There is an immediate need to transfer the organization of the Tax Court to the one-roof system under the Supreme Court.

From the formal legal point of view, there is a vertical de synchronization between the Law on Judicial Power, the Law on Tax Court and the Law on the Military Court. Consequently, structural judicial power is not yet a fully integrated justice system. The reason the Military Court and the Tax Court have not yet been integrated into the one-roof system of the Supreme Court is due to the characteristics of military life, in which the commander plays a central role. While in the case of the Tax Court it is due to the specific characteristics related to collecting taxes which is under the control of the Minister of Finance.

In order for a truly independent and impartial judicial power to materialize, the tax court should be handed over and its entire organization should be transferred to the Supreme Court, following other judiciary bodies the organization of which has already been transferred to the Supreme Court.

Specifically in the case of the military court, related to the world of the military, in which the commander holds central power in leadership. With due observance of the specific conditions prevailing in military circles, only the organizational aspect should remain in the hands of the commander, while the organization of the administrative and financial aspects should also be transferred to the Supreme Court.

The main principles of a state based on the rule of law are legality, an independent judiciary, and the protection of human rights. The judiciary must be "free" from influence by the government or by any other party. The recognition that judicial power should be independent, free from any influence by other branches of power, is a universally accepted principle. ${ }^{49}$ Judicial power is independent state power for administering the judicature and upholding justice based on Pancasila, aimed at the materialization of the State of The Republic of Indonesia based on the rule of law.

The primary task of the courts implementing judicial poweris to receive, examine and adjudicate as well as to settle every dispute filed with them. ${ }^{50}$ In adjudicating, each court has certain authority or absolute competence (attributie van rechtsmacht).

Yahya Harahap states that the basic claim of "the independence of the judiciary", in addition to enforcing justice in an impartial manner (impartiality), being entirely free from the influence of disputing parties, it also has to be free from the influence and the grip of the executive or "independence from

${ }^{49}$ Bagir Manan and Kuntana Magnar, Beberapa Masalah Hukum Tata Negara Indonesia, (Some Constitutional Law Related Issues in Indonesia), Bandung: Alumni, 1993, p. 160.

${ }^{50}$ SudiknoMertokusumo, HukumAcaraPerdata Indonesia, (Indonesian Law of Civil Proceedings), Sixth Edition, Yogyakarta: Penerbit Liberty, 2002, p. 75. 
the executive power". The courts constituting judicial power as intended herein must be independent from the executive power. The main purpose of independence from executive influence and power involves two aspects, namely, first, to ensure the implementation of fair and just trial. Second, to enable the materialization of the above mentioned ideals in Indonesia's judicial power in line with the Broad State Policy Outlines for 1999-2004 which reaffirms the materialization of judiciary bodies which are independent and free from influence by the executive and any other parties, the administration of the judicial process in a timely, easy, low cost and open manner, free from corruption and nepotism. Such directives and policy are also certainly in line with the characteristics of a state based on the rule of law.

\section{Bibliography}

\section{Books}

Asshiddiqie, Jimly.(2007). Pokok-Pokok Hukum Tata Negara Indonesia Pasca Reformasi, (The Principles of Indonesian Constitutional Law in the PostReform Era).Buana Ilmu Populer kelompok Gramedia, Jakarta.

Budiarjo, Miriam. (2000). Dasar-Dasar Ilmu Politik, (The Fundamentals of Political Science).Ed. XI, PT. Gramedia Pustaka Utama, Jakarta.

Harahap, M. Yahya. (2008). Hukum Acara Perdata, (Civil Procedural Law). Jakarta: Sinar Grafika.

Hasan, Hasbi. (2010). Kompetensi Peradilan Agama Dalam Penyelesaian Sengketa Ekonomi Syariah, (The Competence of the Religious Court in the Settlement of Sharia Economy Disputes). Gramata Publishing, Jakarta.

Mahendra, Yusril Ihza. (1996). Dinamika Tata Negara Indonesia, Kompilasi Aktual Masalah Konstitusi Dewan Perwakilan dan Sistem Kepartaian, (The Dynamics of Indonesian Constitutional Law, A Compilation of Current Constitutional Issues Related to the House of Representatives and the Party System). Gema Insani Press, Jakarta.

Manan, Bagir, Magnar, Kuntana. (1996). Beberapa Masalah Hukum Tata Negara Indonesia, (Some Constitutional Law Related Issues in Indonesia). Alumni, Bandung.

Manan, Bagir. (2005). Sistem Peradilan Berwibawa, (Suatu Pencarian), (A Judicial System With Recognized and Observed Authority, (A Quest). Yogyakarta: UII Press.

Mertokusumo, Sudikno.(2002). Hukum Acara Perdata Indonesia, (Indonesian Law of Civil Proceedings). Sixth Edition. Yogyakarta: Penerbit Liberty.

Montesquieu, Charles Louis De Secondad. (2007). The Spirit of Law, (Transl) M. Khoiril Anam. Dasar - Dasar Ilmu Hukum dan Ilmu Politik, (The Fundamentals of the Science of Law and Political Science). Nusa Media Bandung.

Mujahidin, Ahmad.(2007). Peradilan Satu Atap di Indonesia, (One-Roof Judicial System in Indonesia). Refika Aditama, Bandung.

Nasution, Bahder Johan. (2011). Negara Hukum dan Hak Asasi Manusia, (State Based on the Rule of Law and Human Rights). Mandar Maju, Bandung. 
Pompe, Sebastian. (2012). Runtuhnya Institusi Mahkamah Agung, (The Collapse of the Institution of the Supreme Court). Jakarta: Lembaga Kajian dan Advokasi untuk Independensi Peradilan.

Pot, C.W. Van Der, Donner, A.M. (1989). Handboek van het Nederlandse Staatsrecht. Tjeek Willink, zwole.

Sibuea, Hotma P. (2010). Asas Negara Hukum, Peraturan Kebijakan, Asas-asas Umum Pemerintahan yang Baik, (The Principles of State Based on the Rule of Law, Policy Regulations, General Principles of Good Governance). Penerbit Erlangga, Jakarta.

Soekanto, Soerjono, Mamudji, Sri. (2009). Penelitian Hukum Normatif, (Normative Legal Research). Raja Grafindo Persada, Jakarta.

Soemitro, Ronny Hanitijo.(1990).Metodologi Penelitian Hukum dan Jurimetri, (Legal Research Methodology and Jurimetri). Ghalia Indonesia, Jakarta.

Wohjono, Padmo. (1982). Indonesia Negara Berdasarkan atas Hukum, (Indonesia, A State Based on the Rule of Law). Ghalia Indonesia, Jakarta.

Zaini, Abdullah. (1991). Pengantar Hukum Tata Negara, (Introduction to Constitutional Law). Pustaka Sinar Harapan, Jakarta.

Law

The Republic of Indonesia. The 1945 Constitution.

Law No. 14 Year 1970 concerning the Basic Provisions on Judicial Power. Law No. 35 Year 1999 concerning the Amendment to Law No. 14 Year 1970.

Law No 4 Year 2004 concerning Judicial Power.

Law No. 48 Year 2009 concerning Judicial Power

Law No. 5 Year 1986 and Amendment to Law No.51 Year 2009 concerning the State Administration Court.

Law No.7 Year 1989, Law No.3 Year 2006 and Law No.50 Year 2009 concerning the Religious Court.

Law No. 31 Year 1997 concerning the Military Court.

Law No. 14 Year 2002 concerning the Tax Court.

\section{Papers}

Irsyad, Syamsuhadi. Eksistensi Peradilan Agama Pasca Lahirnya Law No. 3 Year 2006, (The Existence of the Religious Court Following the Adoption of Law No. 3 Year 2006). Paper, July 10, 2006.

Arieflawyer.blogspot.com/Gerai Hukum, Masalah Teknis Yudisial, Uudicial Technical Issues). 